\title{
Diel movement patterns of ocean sunfish Mola mola off southern California
}

\author{
Daniel P. Cartamil, Christopher G. Lowe* \\ Department of Biological Sciences, 1250 Bellflower Blvd., California State University, Long Beach, California 90840, USA
}

\begin{abstract}
Ocean sunfish Mola mola are a seasonally common inhabitant of southern Californian waters, and comprise the largest bycatch component ( $29 \%$ of total catch) of the California drift gillnet fishery for swordfish. We used temperature and depth-sensing acoustic transmitters to quantify the fine-scale movement patterns of ocean sunfish near Santa Catalina Island, California. Eight ocean sunfish were tracked continuously over 24 to $72 \mathrm{~h}$ periods, during which oceanographic data were collected every $2 \mathrm{~h}$. Geographical position and depth of tracked fish were analyzed in relation to oceanographic data and time of day. Ocean sunfish traveled a mean distance of $26.8 \pm 5.2( \pm \mathrm{SD}) \mathrm{km} \mathrm{d}^{-1}$. Horizontal movements were characterized by a significant decrease in rate of movement (ROM) during the first $6 \mathrm{~h}$ of night (median $\left.\mathrm{ROM}=0.76 \mathrm{~km} \mathrm{~h}^{-1}\right)(\mathrm{SD}=0.31$ ) as compared to the remaining nighttime period (median $\mathrm{ROM}=1.00 \mathrm{~km} \mathrm{~h}^{-1}$ ) $\left(\mathrm{SD}=0.39\right.$ ), whereas daytime ROM (median $\mathrm{ROM}=1.22 \mathrm{~km} \mathrm{~h}^{-1}$ ) ( $\mathrm{SD}=0.58$ ) was significantly higher than either nighttime period. Horizontal movements were highly directional, with angular concentration values $(r)$ as high as 0.765 over the duration of entire tracks. Nocturnal vertical movements were confined to the surface mixed layer and thermocline, while diurnal vertical movements were often characterized by repeated dives below the thermocline. A significant relationship was found between maximum dive depth and the post-dive period spent in the mixed layer, suggesting that ocean sunfish may behaviorally thermoregulate between deeper daytime dives. The observed depth-distribution patterns of ocean sunfish indicate that lowering the depth of gillnets in the water column could significantly reduce bycatch of this species in the California drift gillnet fishery.
\end{abstract}

KEY WORDS: Acoustic telemetry $\cdot$ Pelagic tracking $\cdot$ Drift gillnet fishery $\cdot$ Bycatch $\cdot$ Thermoregulation Resale or republication not permitted without written consent of the publisher

\section{INTRODUCTION}

The ocean sunfish Mola mola, a large pelagic zooplanktivore (Fraser-Bruner 1951), frequently comprises a large percentage of the bycatch in drift gillnet fisheries. A survey of the Spanish drift gillnet fishery in the Mediterranean Sea indicated that ocean sunfish represented between 71 and $93 \%$ of the total catch between 1992 and 1994 (Silvani et al. 1999). In the eastern Pacific, ocean sunfish numerically comprise $29 \%$ of the total catch of the California drift gillnet fishery for swordfish-far outnumbering the target species (D. Petersen, National Marine Fisheries Service [NMFS], unpubl. data). Reducing bycatch of abundant non-target species is becoming a high priority in fisheries management due to increased concerns over ecosystem-wide fishery effects (Larkin 1996, Sherman \& Duda 1999, Pitcher 2001). However, development of bycatch reduction strategies is dependent on knowledge of fish movement patterns and distributions relative to fishing methods.

Presently, very little is known about the biology or behavior of ocean sunfish. They inhabit subtropical to temperate pelagic waters worldwide (Fraser-Bruner 1951, Miller \& Lea 1972), and are the largest known teleosts, with total lengths of up to $3 \mathrm{~m}$ and weights of almost $2000 \mathrm{~kg}$ (Gudger 1928). Surprisingly, ocean sunfish attain these massive proportions on a diet reported to consist primarily of gelatinous zooplankton (Linton 1901, Fraser-Bruner 1951, McCann 1961, MacGinitie \& MacGinitie 1968, Hooper et al. 1973, Sommer et al. 1989). Morphologically, ocean sunfish possess 
many distinctive traits, such as a stiff truncated body, use of the dorsal and anal fins for primary propulsion, and a rudder-like caudal fin, or clavus (Fraser-Bruner 1951). These characteristics have led to much speculation regarding the locomotory abilities and behavior of ocean sunfish. For example, Myers \& Wales (1930) reported that ocean sunfish are active swimmers, whereas Gudger (1928) and Dawson (1965) describe them as sluggish, inefficient swimmers, passively carried by water currents. Dean (1913) suggested that ocean sunfish morphology was more characteristic of deeper water species, although they are most frequently observed during daylight hours 'basking' at the sea surface, behavior some authors have attributed to illness (Fraser-Bruner 1951, McCann 1961, Schwartz $\&$ Lindquist 1987) or solicitation of cleaner fish (Threlfall 1967, Love 1996). In addition, observations of the drift gillnet fishery indicate that ocean sunfish are caught at night in gillnets set at depths between 12 and $50 \mathrm{~m}$ (D. Cartamil pers. obs.). The large number of ocean sunfish caught in these nets indicates that the nighttime depth distribution of ocean sunfish must at least partially include this range.

Based on the limited information available on ocean sunfish distributions, we hypothesized that they are vertical migrators, occurring near the surface by day and deeper by night. To test this hypothesis, we conducted an acoustic telemetry tracking study of Mola mola off southern California. Additional goals of this study were to ascertain the preferred depth range of ocean sunfish, and quantify fine-scale horizontal and vertical movement patterns relative to oceanographic factors.

\section{MATERIALS AND METHODS}

Acoustic telemetry and oceanographic measurements. Ocean sunfish were spotted basking at the surface, or found in association with kelp patties. Once located, fish were captured by dipnetting and brought aboard the $6.6 \mathrm{~m} \mathrm{R} / \mathrm{V}$ 'Callinectes', where they were measured and externally tagged with a temperature and depth-sensing acoustic transmitter (Vemco, Model V22TP, $22 \mathrm{~mm}$ diameter $\times 100 \mathrm{~mm}$ length, frequencies 34 to $40 \mathrm{kHz}$ ). Transmitters were attached to a nylon dart (Floy Tag Mfg. FIM-96) via an $8 \mathrm{~cm}$ length of $100 \mathrm{lb}$ $(45.36 \mathrm{~kg})$ test monofilament line. The nylon dart was inserted approximately $2 \mathrm{~cm}$ deep in the integument immediately anterior to the clavus, below the trailing edge of the dorsal fin. Preliminary dissections done in the laboratory confirmed that the integument in this region is thick enough to accommodate the dart without it entering the subcutaneous musculature and possibly affecting swimming behavior. The fish were then released at the site of capture after a handling time of less than 5 min.
Transmitters encoded depth and temperature information by varying pulse interval. The acoustic output of the transmitters was detected using a fixed directional hydrophone mounted through the vessel's hull, and decoded by a receiver unit (Vemco, Model VR60) mounted above the boat console. Depth and temperature data, displayed on the receiver's LED screen, were recorded manually every $3 \mathrm{~min}$ along with the vessel's GPS-derived location. We attempted to maintain the farthest possible distance from the fish while still able to decode the acoustic signal at the lowest receiver gain setting. In calm sea conditions, transmitter range tests showed this distance to be approximately $300 \mathrm{~m}$. Maximum range at maximum receiver gain was approximately $1 \mathrm{~km}$. To accommodate for signal attenuation during periods of rough sea conditions, receiver gain was increased to avoid approaching the animal too closely. Thus, the boat was kept at a relatively constant distance from the fish, and for the purposes of data analysis, the boat's geographic position was assumed to be the same as the fish's (Brill et al. 1999).

A sonde unit (YSI, Model 6600) was deployed every 2 to $3 \mathrm{~h}$, to a depth of $42 \mathrm{~m}$, providing an environmental profile over the course of each track. For the last 2 tracks (Tracks 7 and 8), a longer cable allowed deployment of the unit to $70 \mathrm{~m}$. Oceanographic factors measured with the sonde included depth, water temperature, light intensity and chlorophyll concentration.

Data analysis. Each track was plotted on a digital chart of the San Pedro Channel using ArcView GIS Version 3.2. Distances between successive positions were determined with the animal movement analyst extension (AMAE; Hooge \& Eichenlaub 2000) for ArcView GIS. We calculated rate of movement (ROM) by dividing distance between successive points by the sampling interval. Daytime and nighttime ROMs were categorized for each fish based on local times of sunrise and sunset. Pooled daytime and nighttime ROM data from all fish were compared using a MannWhitney $U$-test. In order to examine patterns in ROM on a finer scale, distances traveled over $1 \mathrm{~h}$ periods were summed to provide hourly ROM and plotted against time of day.

Circular statistics were used to examine linearity of various tracks and track segments. For these analyses, we used AMAE to calculate mean bearing and angular concentration. Angular concentration $(r)$ is a relative measure of linearity, ranging from 0 to 1 , with a value of 1 representing absolute linearity (Batschelet 1981). Point-to-point bearings were determined with the 'path with distances and bearings' extension to ArcView (Jenness 2001), and analyzed using Rayleigh's $z$-test to determine significant linearity (nonrandomness) of movement paths. 
Vertical movements were examined by plotting each fish's depth readings against time of day to construct a depth profile for each tracking period. Temperature, chlorophyll concentration and light data obtained by sonde deployments were overlaid upon the depth profiles to evaluate the possible extent to which various oceanographic factors influenced the vertical movements of the fish.

Data obtained from the transmitter depth sensors were used to determine diel depth distributions. Percentage frequency of occurrence at depth was compared for all fish between day and night.

The descent and ascent rates, maximum dive depth, and durations of post-dive periods in the surface mixed layer were quantified for each discrete diving period. Diving periods were defined as vertical excursions from the surface mixed layer through the thermocline and back. The durations of post-dive periods were analyzed in relation to maximum dive depth using a linear regression. Dive descent and ascent rates were compared with a paired $t$-test.

\section{RESULTS}

Eight ocean sunfish, ranging in length from 73 to $151 \mathrm{~cm}$ total length (TL; Table 1), were tagged and tracked off southern California. Seven of the ocean sunfish were caught off the northern coast of Santa

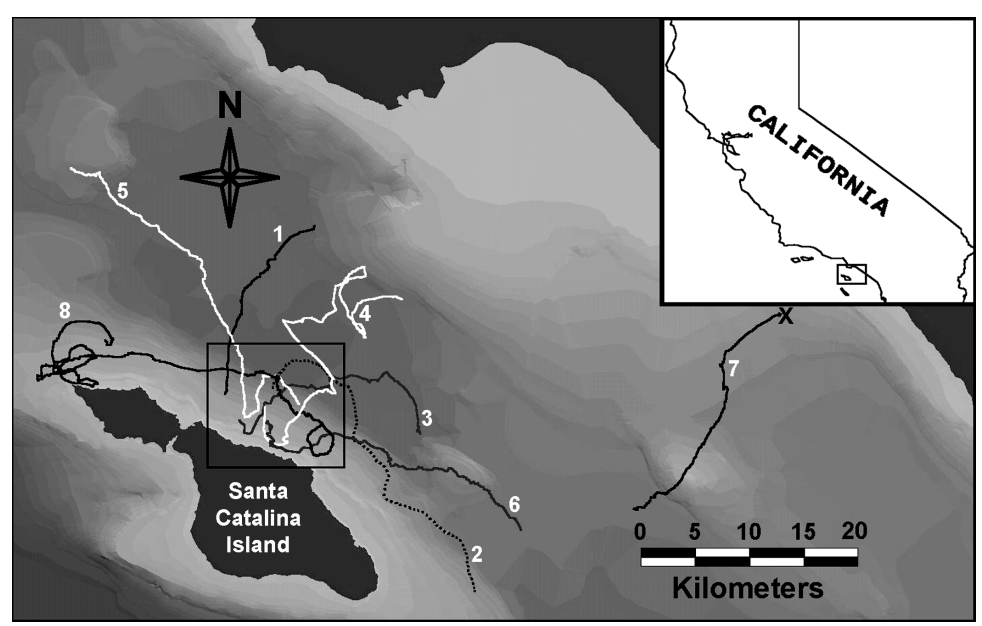

Fig. 1. Mola mola. Movements of 8 ocean sunfish tracked by acoustic telemetry, near Santa Catalina Island, California. Inset shows the general tracking area in relation to California. Darker gray indicates deeper water (max. depth: ca. $900 \mathrm{~m}$ ). All tracks originated within the boxed area north of Santa Catalina Island, except for Track 7 (origin at X)
Catalina Island and 1 was caught approximately $50 \mathrm{~km}$ northeast of the island, close to the mainland coastline (Fig. 1). Six of the 8 tagged fish showed an immediate stress response consisting of 1 or more short-term deep dives, returning to more characteristic swimming depths after periods of 1 to $5 \mathrm{~h}$. Therefore, data acquired during these periods were not included in analyses.

Overall, fish moved $26.8 \pm 5.2(\bar{x} \pm \mathrm{SD}) \mathrm{km} \mathrm{d}^{-1}$. Horizontal movements were characterized by a significant decrease in ROM during the first $6 \mathrm{~h}$ of night (median $\left.\mathrm{ROM}=0.76 \mathrm{~km} \mathrm{~h}^{-1} ; \mathrm{SD}=0.31\right)$ as compared to the remaining nighttime period (median $\mathrm{ROM}=1.00 \mathrm{~km} \mathrm{~h}^{-1}$; $\mathrm{SD}=0.39$ ), whereas daytime ROM (median ROM = $1.22 \mathrm{~km} \mathrm{~h}^{-1} ; \mathrm{SD}=0.58$ ) was significantly higher than either nighttime period (Kruskal-Wallis test, $\mathrm{p}<0.001$; Fig. 2). In many cases, horizontal movements were also highly directional, with $r$ values as high as 0.765 over the duration of entire tracks (Fig. 3, Table 1).

Most of the tracked fish displayed a distinct diel pattern of vertical movement (Fig. 4). During nighttime periods, vertical movements were confined to the warmer near-surface waters (mixed layer) above or within the thermocline. The upper limits of the thermocline ranged from 10 to $20 \mathrm{~m}$ in depth, while the lower limits of the thermocline typically ranged from 30 to $40 \mathrm{~m}$. Among all fish, only one descent below the thermocline was noted during nighttime periods. Daytime periods, in contrast, were often characterized by repeated dives below the thermocline, though the extent of this pattern varied among fish. These dives (generally to 40-150 m) were typically short in duration (mean dive duration $11.2 \pm 9.5 \mathrm{~min})$, and were immediately followed by a return to the mixed layer, where 


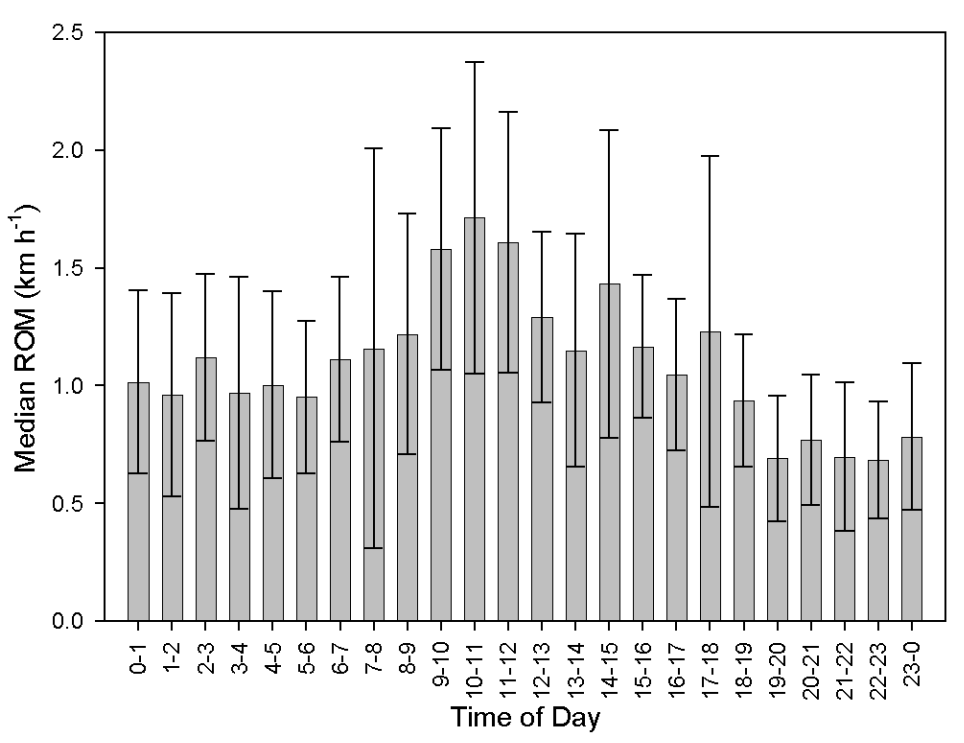

Fig. 2. Mola mola. Hourly rate of movement $\left(\mathrm{ROM} \mathrm{km} \mathrm{h}^{-1}\right.$; median $\pm \mathrm{SD}$ ) of ocean sunfish tracked over a diel cycle

fish still spent the majority of the daylight period (Fig. 5). The maximum dive depth observed was $392 \mathrm{~m}$. During these vertical excursions, the fishes experienced temperatures ranging from 21.0 to $6.8^{\circ} \mathrm{C}$.

A significant relationship was found when maximum dive depth was plotted against duration of the postdive period after the fish returned to the mixed layer (linear regression, $\mathrm{R}^{2}=42.1 \%, \mathrm{p}<0.001$; Fig. 6). There was no significant difference between the mean des-

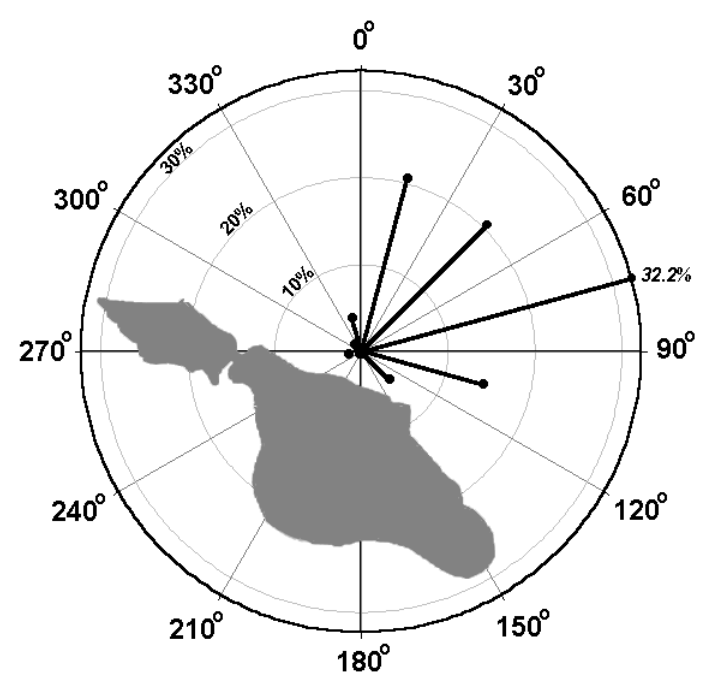

Fig. 3. Mola mola. Circular plot of Ocean Sunfish 1 movement, bearing concentrations over the course of a $29 \mathrm{~h}$ track. $0^{\circ}$ represents due north. Individual bearings are pooled in $30^{\circ}$ intervals, and concentric radial lines (light gray) indicate \% of points within each interval. Angular concentration (r): 0.765 ; mean bearing: $59.2^{\circ}$ cent rate $\left(8.4 \pm 5.6 \mathrm{~m} \mathrm{~min}^{-1}\right)$ and ascent rate of dives $\left(7.7 \pm 5.6 \mathrm{~m} \mathrm{~min}^{-1}\right.$; paired $t$-test, $t=1.40, \mathrm{p}=$ 0.166). Additionally, no correlation was found between sizes of tracked fish (TL) and mean dive depths (Pearson's correlation coefficient: -0.183 , $\mathrm{p}=0.69$ ).

The depths of the chlorophyll maxima were not correlated with fish depths (Pearson's correlation coefficient: $-0.107, p=0.37$ ). Mean chlorophyll concentration at these maxima was $4.8 \mu \mathrm{g} \mathrm{l}^{-1}$ (range 2.5 to $7.9 \mu \mathrm{g} \mathrm{l}^{-1}$ ). Vertical excursions were typically initiated 10 to $15 \mathrm{~min}$ after civil twilight, corresponding to a light intensity of between 2700 and 8100 lux at $1 \mathrm{~m}$ depth.

\section{DISCUSSION}

\section{Horizontal movements}

Ocean sunfish are commonly regarded as planktonic fish, primarily transported by oceanic currents (McCann 1961, Holt 1965, Lee 1986). However, those tracked in this study were observed to move a mean of $26.8 \mathrm{~km} \mathrm{~d}^{-1}$, with the highest ROM (peak ROM: $3.2 \mathrm{~km} \mathrm{~h}^{-1}$ ) occurring during the daytime. Estimating the degree to which fish movement was attributable to ocean currents is problematic due to the complexity of near-surface circulation patterns in the San Pedro Channel (DiGiacomo \& Holt 2001) and lack of current monitoring during tracks. Current circulation in the San Pedro Channel is dominated by the California Counter-current, a branch of the southeastward-flowing California Current that turns northward and flows inshore through the southern California Bight (Hickey 1992). The typical mean northwesterly current velocity in the San Pedro Channel during late summer and fall is 0.18 to $0.36 \mathrm{~km} \mathrm{~h}^{-1}$ (4.32 to $8.64 \mathrm{~km} \mathrm{~d}^{-1}$; Bakus 1989, Hickey 1992). Only 2 of the 8 tracked fish traveled northwesterly, while 3 traveled perpendicular to the California Counter-current, and 3 fish followed a southeasterly trajectory. This clearly indicates that ocean sunfish are active swimmers, not substantially affected by the velocity or direction of the currents. While it may not be surprising that other pelagic species such as tunas show minimal influence by ocean currents due to their swimming abilities, it is interesting to note that the ROMs of ocean sunfish tracked in this study are similar to those found by Block et al. (1997) for yellowfin tuna Thunnus albacares $\left(1.7\right.$ to $3.2 \mathrm{~km} \mathrm{~h}^{-1}$ ) in the southern California Bight.

Ocean sunfish horizontal movements were often highly directional; 7 of the 8 fish tracked exhibited significantly non-random movements over the entire 


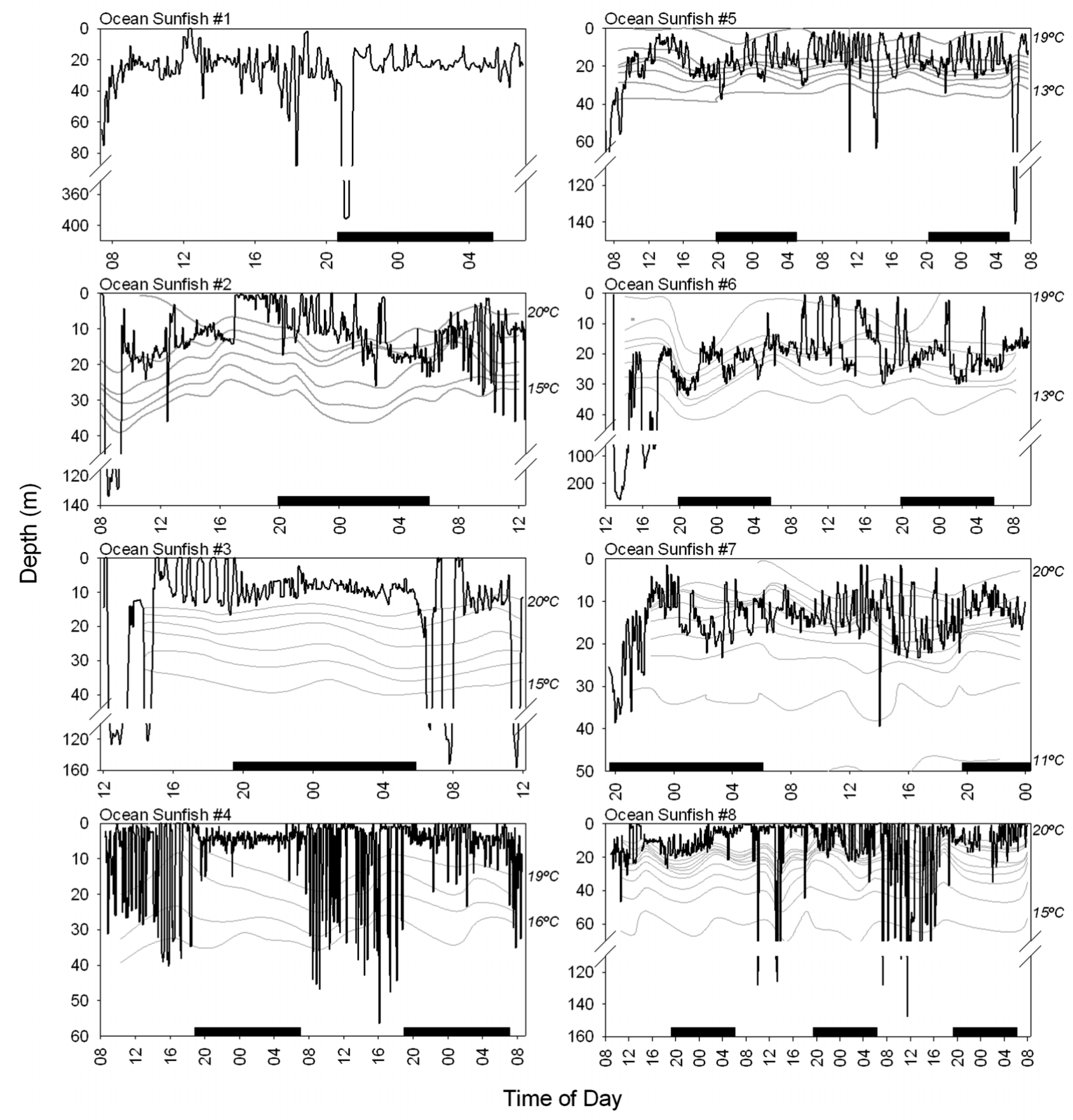

Fig. 4. Mola mola. Dive profiles of Ocean Sunfish 1 to 8 over the course of each track. Gray lines: $1^{\circ} \mathrm{C}$ isotherms; max. and min. temperatures are given on the right. No water temperature data were collected during the tracking of Ocean Sunfish 1. Black horizontal bars indicate nighttime periods

tracking period. Even in cases where the overall $r$ for a track was low, extended periods of the track often retained high $r$-values. For example, Track 8 had a low $r$-value of 0.189 over a $72 \mathrm{~h}$ period. However, over the $30 \mathrm{~h}$ period from 14:00 h on 19 September 2002 to 20:00 h on 20 September 2002, the track had an $r$-value of 0.501 , significantly non-random $(p<0.001)$. Direc- tional movements are common among pelagic fish studied, and have been noted in various pelagic sharks (Carey \& Scharold 1990, Klimley 1993, Holland et al. 1999), blue marlin Makaira nigricans (Block et al. 1992), and yellowfin tuna (Holland et al. 1990b). While the orientation cues of directed movements are difficult to identify, some fish have been shown to orient to 


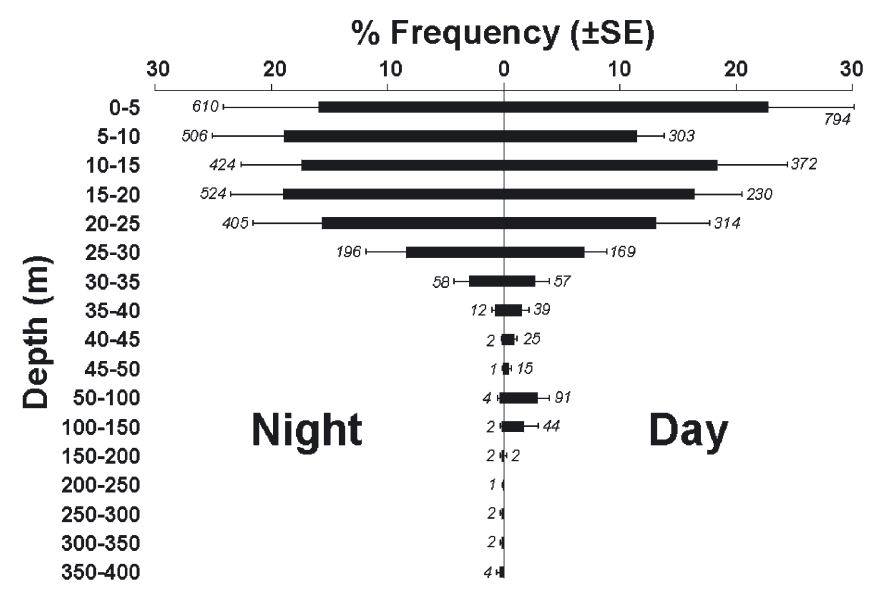

Fig. 5. Mola mola. Depth distributions (\% frequency; mean \pm $\mathrm{SE})$ calculated from individual fish at each depth interval. Depth readings of 0 to $50 \mathrm{~m}$ are pooled in $5 \mathrm{~m}$ intervals, and readings of 50 to $400 \mathrm{~m}$ are pooled in $50 \mathrm{~m}$ intervals. Total number of depth readings are given in italics. All nighttime depth positions below $40 \mathrm{~m}$ are from 1 dive to $392 \mathrm{~m}$ during Track 1

magnetic cues (Walker et al. 1984, Moore et al. 1990, Kobayashi \& Kirschvink 1995). As no obvious or detectable celestial or ocean current orientation was observed, magnetoreception could explain the directed movements of ocean sunfish in the pelagic environment.

The general trend of movement was away from Santa Catalina Island, though the direction of travel was highly variable. It is unlikely that the high degree of directionality exhibited during these movements was influenced by the island itself, since directed movements continued even after fish were well offshore, over the deepest portions of the San Pedro Basin. Block et al. (1992) reported directed movements

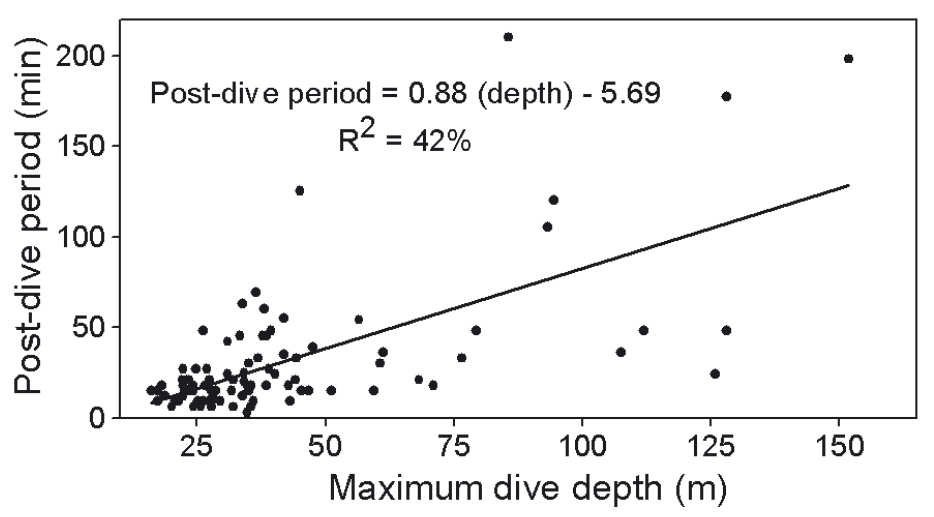

Fig. 6. Mola mola. Relationship between maximum depths of all dives and durations of corresponding post-dive periods in the mixed layer of blue marlin away from the island of Hawaii, suggesting that these fish may be temporarily visiting the island during longer migratory movements. Although the temporal distribution patterns of ocean sunfish in the eastern Pacific are not well known, their seasonal occurrence in locales such as Monterey Bay and Santa Catalina Island, California, suggests migratory activity, presumably within a preferred temperature range (Myers \& Wales 1930, Lee 1986). As such, Santa Catalina Island may represent a temporary 'stoppingover' location, due to abundant prey, warm water, and the presence of kelp beds and paddies (under which they are often cleaned by halfmoons Medialuna californiensis, and other fishes; Hixon 1979).

\section{Vertical movements}

Six of the 8 fish showed an immediate deep-dive response after release, in which the fish often reached their greatest recorded depths before returning to more 'typical' behavior. This reaction was brief $(<3 \mathrm{~h})$ in most cases, and is well documented as a short-term stress response in various acoustically tagged pelagic fishes (e.g. Sciarrotta \& Nelson 1977, Carey \& Scharold 1990, Holland et al. 1990a, Block et al. 1992, Holts \& Bedford 1993). There also may have been some inhibition of vertical movement for a short time following the initial stress-related dive, but it is unclear whether this was due to tagging stress. Carey \& Scharold (1990), Block et al. (1997) and (1992) observed similar behavior in blue sharks, yellowfin tuna and blue marlin, respectively, wherein diving patterns were less welldeveloped over approximately the first $12 \mathrm{~h}$ of tracking. Although it is difficult to determine the degree to which capture stress impacts post-release behavior, the occurrence of diel vertical movement patterns may provide some indication of speed of recovery that may only be obvious over longer tracks.

Most tracked fish showed a distinct diel diving pattern with daytime periods characterized by brief, repeated dives below the thermocline. This diel pattern is likely induced by changes in light intensity. Changes in diel light intensity are thought to initiate similar bounce diving behavior in other pelagic fishes, such as blue sharks Prionace glauca (Carey \& Scharold 1990), swordfish Xiphias gladius (Carey \& Robison 1981), and some tunas (Holland et al. 1990b, Kitagawa et al. 2000). Various explanations have been posited for this behavior, most of which focus on prey acquisition as the primary motivation for diving activity.

The spatio-temporal dynamics of ocean sunfish prey suggest that the movement patterns of ocean sunfish could have evolved as a means of foraging on vertically migrating organisms. Ocean sunfish are widely 
reported to feed primarily on gelatinous zooplankton, including salps, medusae and ctenophores (Linton 1901, Suyehiro 1942, Fraser-Bruner 1951, McCann 1961, MacGinitie \& MacGinitie 1968, Hooper et al. 1973, Sommer et al. 1989), although the fragility and digestive state of these ingested organisms has often precluded identification to species. Many common gelatinous zooplankton found in southern California waters are vertical migrators, occurring near the surface nocturnally and retreating by day to various depths within the vertical distribution range of ocean sunfish (e.g. Bruland \& Silver 1981, Mills 1982, Purcell \& Madin 1991). Therefore, it is possible that ocean sunfish dive during daylight hours to feed on gelatinous zooplankton at their diurnal depths below the thermocline. To further test this hypothesis, concurrent data on prey depth distributions, species composition and evidence of actual foraging is needed.

The vertical movements of ocean sunfish could also serve to increase the probability of prey detection as ocean sunfish ascend or descend through the water column. Ocean sunfish routinely dove to depths in excess of $50 \mathrm{~m}$, and might have experienced increased prey density as they moved through the chlorophyll maxima (high concentrations of phytoplankton), a zone often associated with high zooplankton concentrations (Harris 1988). The chlorophyll maxima during our study were most often situated between 20 and $30 \mathrm{~m}$ depth, though the abundance and species composition of zooplankton associated with local chlorophyll maxima during tracking periods was not determined.

Regardless of the function of daytime diving behavior, there appears to be a strong motivation for ocean sunfish to dive to the colder waters below the thermocline. However, ocean sunfish rarely remained below the thermocline for more than a few minutes, even though surface temperatures in more northern parts of their range can be colder than the temperatures experienced during these dives (Miller \& Lea 1972, Lee 1986). Brill et al. (1999) suggested that due to physiological limitations, the magnitude and rate of change in water temperature, rather than absolute temperature, may limit vertical movements in yellowfin tuna, blue marlin and striped marlin Tetrapturus audax, and the same may be true for ocean sunfish. Periodic ascents to the warm mixed layer, therefore, may be attempts by the fish to rewarm its core body temperature (i.e. behavioral thermoregulation), as was suggested for swordfish Xiphias gladius (Carey \& Robison 1981). Rewarming of the body could be advantageous in terms of increased mobility, digestion, assimilation and growth rates (Wurtsbaugh \& Neverman 1988). Dive 'recovery times' (i.e. the post-dive period) of ocean sunfish spent in the mixed layer increased significantly as a function of maximum dive depth, further support- ing this hypothesis (Fig. 6). While only $42 \%$ of the variance in post-dive time was accounted for by maximum dive depth, it is likely that the varying masses of the fish, varying degrees of thermal variation from the surface to the maximum dive depths, and the amount of prey available to the fish at depth may also explain some of the variability. Further studies where core body temperature is monitored during dive activity are needed in order to better understand potential thermoregulation in ocean sunfish.

The vertical movements of ocean sunfish may also be limited by dissolved oxygen concentration. Four of the ocean sunfish reached depths approaching $150 \mathrm{~m}$ during dives. During the months of August through October, average $\mathrm{O}_{2}$ concentrations at $150 \mathrm{~m}$ in the study area are between 2.5 and $3.0 \mathrm{ml} \mathrm{l}^{-1}$ (Wyllie \& Lynn 1971), a range known to induce avoidance responses in many marine fish species (reviewed in Davis 1975 \& Brill 1994). While the physiology of ocean sunfish is not well studied, oxygen concentration may also play a role in defining their habitat preferences. Therefore, as noted by Carey \& Robison (1981), recovery time spent in the mixed layer by pelagic fishes may be related not only to temperature, but to recovery from hypoxia, particularly for deeper-diving fishes.

In contrast to the daytime vertical movements of ocean sunfish, nocturnal vertical distribution was confined to the waters within the thermocline, and more typically to the mixed layer. This nocturnal compression of depth distribution was concomitant with a significant decrease in horizontal ROM, a pattern not previously described for any pelagic fish species. One possible explanation for this behavior is that ocean sunfish actively forage in the mixed layer by night, but have little need for movement because vertically migrating prey are near the surface. However, zooplankton are typically patchy in distribution (Steele 1976, Mackas et al. 1985) and greater horizontal movement might be expected from a fish exploiting a patchy resource in order to increase prey encounter rates. Another possibility is that ocean sunfish become relatively quiescent in the warmer mixed layer by night, which may confer many of the same metabolic advantages as the aforementioned post-dive period. This hypothesis is supported by the lower nighttime ROMs, as higher ROMs are usually presumed to be associated with foraging in other pelagic fishes (Sciarrotta \& Nelson 1977).

Curiously, the only instance in which a fish descended below the thermocline during the nighttime period was also the greatest depth recorded for any tracked fish. Almost $1 \mathrm{~h}$ after sunset, Ocean Sunfish 1 rapidly dove to $392 \mathrm{~m}$ (corresponding to an ambient water temperature of $6.8^{\circ} \mathrm{C}$ ). Depth data were taken on a minute-by-minute basis during this dive period, and 
indicated that the fish descended at a rate of $53 \mathrm{~m}$ $\min ^{-1}, 6$ times faster than typical descents observed during daytime dives $\left(8.4 \pm 5.6 \mathrm{~m} \mathrm{~min}^{-1}\right)$, and ascended at a rate of $25 \mathrm{~m} \mathrm{~min}^{-1}$. Based on the incongruous time period, swift descent rate, and the fact that other deep dives were typically associated with the initial posthandling stress, this dive could possibly represent a predator avoidance response. Ocean sunfish predators include large sharks (Fergusson et al. 2000, S. Kohin pers. comm.) and California sea lions Zalophus californianus (T. Thys pers. comm.), both of which are commonly found in the waters off Santa Catalina Island.

\section{Implications for drift-gillnet fishery management}

An extensive drift gillnet fishery exists off the western coast of the United States, with most fishing activity concentrated off southern California. Typically, fishing gear consists of a $2.2 \mathrm{~km}$ (length) $\times 30$ to $40 \mathrm{~m}$ (depth) large-mesh gillnet that hangs vertically in the water column at a minimum depth of $12 \mathrm{~m}$ to avoid marine mammal interactions. Drift gillnets are usually set at dusk and retrieved before dawn (D. Cartamil pers. obs.).

Because the nocturnal depth preference of ocean sunfish observed in this study was above the thermocline, it is not surprising that this species is often caught in the upper portions of gillnets (D. Cartamil pers. obs.). Ocean sunfish tracked in this study were found to spend $75 \%$ of the time within the upper $20 \mathrm{~m}$ of the water column at night. These data suggest that lowering the minimum depth at which drift gillnets are set could result in a substantial decrease of ocean sunfish bycatch. Based on our data, increasing the minimum mandated net depth to $20 \mathrm{~m}$ would likely result in a reduction of ocean sunfish bycatch of 20 to $25 \%$. However, the depth distributions of swordfish and thresher sharks Alopias sp. in the eastern Pacific are not well known, and therefore it is difficult to predict the effect of lowering drift gillnets on catch rates of these target species.

Additionally, NMFS observer data indicates that the majority of drift gillnet-caught ocean sunfish are released alive (D. Petersen, NMFS, pers. comm.), and therefore there is a general belief among management personnel and fishermen that ocean sunfish populations are unaffected by drift gillnet interactions. However, many of the released fish show obvious signs of fishery-induced trauma, including loss of protective mucus coating, abrasions, bleeding, and gill discoloration resulting from air exposure (D. Cartamil pers. obs.). Therefore, an assessment of post-release mortality is needed in order to make informed decisions regarding drift gillnet fishery management.
Acknowledgements. We gratefully acknowledge the PADI AWARE Foundation, Blue Planet Foundation, NHK Films Japan and the American Institute of Fisheries Research Biologists for funding assistance. Additional funding and equipment was provided by the California State University, Long Beach, Department of Biological Sciences. We thank J. Mc Kibben, J. McIlrath and C. Zamfir for invaluable technical assistance in the custom construction of the hull-mounted hydrophone system and other tracking equipment, and B. Mercier for assistance with boat maintenance. Thanks also go to $\mathrm{H}$. Dewar and R. Wilson for their useful advice regarding this project and manuscript and to D. Sun for piloting reconnaissance flights over Santa Catalina Island. Multi-day pelagic tracks aboard a small boat can be arduous, if not hallucination-inducing, and we would like to thank D. Topping, Y. Papastamatiou, J. Vaudo, G. Hoisington, B. Hummel, C. Jackson and S. Kohin for their assistance in tracking.

\section{LITERATURE CITED}

Bakus GJ (1989) The marine biology of southern California. Occas Pap Allen Hancock Found New Series 7:1-61

Batschelet E (1981) Circular statistics in biology. Academic Press, London

Block BA, Booth DT, Carey FG (1992) Depth and temperature of the blue marlin, Makaira nigricans, observed by acoustic telemetry. Mar Biol 114:175-183

Block BA, Keen JE, Castillo B, Dewar H, Freund EV, Marcinek DJ, Brill RW, Farwell C (1997) Environmental preferences of yellowfin tuna (Thunnus albacares) at the northern extent of its range. Mar Biol 130:119-132

Brill RW (1994) A review of temperature and oxygen tolerance studies of tuna pertinent to fisheries oceanography, movement models and stock assessments. Fish Oceanogr 3:204-216

Brill RW, Block BA, Boggs CH, Bigelow KA, Freund EV, Marcinek DJ (1999) Horizontal movements and depth distribution of large adult yellowfin tuna (Thunnus albacares) near the Hawaiian Islands, recorded using ultrasonic telemetry: implications for the physiological ecology of pelagic fishes. Mar Biol 133:395-408

Bruland KW, Silver MW (1981) Sinking rates of fecal pellets from gelatinous zooplankton (salps, pteropods, dolioloids). Mar Biol 63:295-300

Carey FG, Robison BH (1981) Daily patterns in the activities of swordfish, Xiphias gladius, observed by acoustic telemetry. Fish Bull 79:277-292

Carey FG, Scharold JV (1990) Movements of blue sharks (Prionace glauca) in depth and course. Mar Biol 106: 329-342

Davis JC (1975) Minimal dissolved oxygen requirements of aquatic life with emphasis on Canadian species: a review. J Fish Res Board Can 32:2295-2332

Dawson CE (1965) Records of two head-fishes (Family Molidae) from the North-Central Gulf of Mexico. Proc La Acad Sci 28:86-89

Dean B (1913) A record sunfish. Am Mus J 32:370-371

DiGiacomo PM, Holt B (2001) Satellite observations of small coastal eddies in the Southern California Bight. J Geophys Res 106:22521-22543

Fergusson IK, Compagno LJV, Marks MA (2000) Predation by white sharks, Carcharodon carcharias (Chondrichthyes: Lamnidae) upon chelonians, with new record from the Mediterranean Sea and a first record of the ocean sunfish Mola mola (Osteichthyes: Molidae) as stomach contents. Environ Biol Fish 58:447-453 
Fraser-Bruner A (1951) The ocean sunfishes (Family Molidae). Bull Brit Mus Nat Hist 1:89-121

Gudger EW (1928) Capture of an ocean sunfish. Sci Mon 26: $257-261$

Harris RP (1988) Interactions between diel vertical migratory behavior of marine zooplankton and the subsurface chlorophyll maximum. Bull Mar Sci 43:663-674

Hickey BM (1992) Circulation over the Santa Monica-San Pedro Basin and Shelf. Prog Oceanogr 30:37-115

Hixon MA (1979) The halfmoon, Medialuna californiensis, as a cleaner fish. Calif Fish Game 65:117-118

Holland K, Brill R, Chang RKC (1990a) Horizontal and vertical movements of Pacific blue marlin captured and released using sportfishing gear. Fish Bull 88:397-402

Holland KN, Brill R, Chang RKC (1990b) Horizontal and vertical movements of yellowfin and bigeye tuna associated with fish aggregating devices. Fish Bull 88:493-507

Holland KN, Wetherbee BM, Lowe CG, Meyers CG (1999) Movements of tiger sharks (Galeocerdo cuvier) in coastal Hawaiian waters. Mar Biol 134:665-673

Holt DE (1965) First recorded ocean sunfish caught off Venezuelan coast. Underwat Nat 3:23-26

Holts DB, Bedford DW (1993) Horizontal and vertical movements of the shortfin mako shark, Isurus oxyrinchus, in the southern California Bight. Aust J Mar Freshw Res 44: 901-909

Hooge P, Eichenlaub E (2000) Animal movements extension to Arcview. Alaska Biological Center, US Geological Survey, Anchorage, AK

Hooper SN, Paradis M, Ackman RG (1973) Distribution of trans-6-hexadecenoic acid, 7-methyl-7-hexadecenoic acid and common fatty acids in lipids of the ocean sunfish, Mola mola. Lipids 8:509-516

Jenness J (2001) Path, with distances and bearings [Arcview 3.x Extension]. Jenness Enterprises, Flagstaff, AZ

Kitagawa T, Nakata H, Kimura S, Itoh T, Tsuji S, Nitta A (2000) Effect of ambient temperature on the vertical distribution and movement of Pacific bluefin tuna Thunnus thynnus orientalis. Mar Ecol Prog Ser 206:251-260

Klimley AP (1993) Highly directional swimming by scalloped hammerhead sharks, Spyrna lewini, and subsurface irradiance, temperature, bathymetry, and geomagnetic field. Mar Biol 117:1-22

Kobayashi A, Kirschvink JL (1995) Magnetoreception and electromagnetic field effects: sensory perception of the geomagnetic field in animals and humans. In: Blank M (ed) Electromagnetic fields: biological interactions and mechanisms. Advances in chemistry series, Vol 250. American Chemical Society, Washington, DC, p 367-394

Larkin PA (1996) Concepts and issues in marine ecosystem management. Rev Fish Biol Fish 6:139-164

Lee DS (1986) Seasonal, thermal, and zonal distribution of the ocean sunfish, Mola mola, off the North Carolina coast. Brimleyana 12:75-83

Linton EL (1901) Parasites of fishes of the Woods Hole region. Bull US Fish Comm 19:405-492

Love RM (1996) Probably more than you want to know about the fishes of the Pacific Coast. Really Big Press, Santa Barbara, CA

Editorial responsibility: Otto Kinne (Editor),

Oldendorf/Luhe, Germany
MacGinitie GE, MacGinitie N (1968) Natural history of marine animals, 2nd edn. McGraw-Hill Book Company, New York

Mackas DL, Denman KL, Abbot MR (1985) Plankton patchiness: biology in the physical vernacular. Bull Mar Sci 37: 652-674

McCann C (1961) The sunfish, Mola mola, in New Zealand waters. Rec Domin Mus 4:7-20

Miller DJ, Lea RN (1972) Guide to the coastal marine fishes of California. Calif Fish Game Bull 157:210

Mills CE (1982) Patterns and mechanisms of vertical distribution of medusae and ctenophores. PhD dissertation, University of Victoria, BC

Moore A, Freake SM, Thomas IM (1990) Magnetic particles in the lateral line of the Atlantic salmon (Salmo salar). Philos Trans Biol Sci 329:11-15

Myers GS, Wales JH (1930) On the occurrence and habits of ocean sunfish (Mola mola) in Monterey Bay, California. Copeia 1:11

Pitcher TJ (2001) Fisheries managed to rebuild ecosystems? Reconstructing the past to salvage the future. Ecol Appl 11:610-617

Purcell JE, Madin LP (1991) Diel patterns of migration, feeding, and spawning by salps in the subarctic Pacific. Mar Ecol Prog Ser 73:211-217

Schwartz FJ, Lindquist DG (1987) Observations on Mola basking behavior, parasites, echeneidid associations, and body-organ weight relationships. J Elisha Mitchell Sci Soc 103:14-20

Sciarrotta TC, Nelson DR (1977) Diel behavior of the blue shark, Prionace glauca, near Santa Catalina Island, California. Fish Bull 75:519-528

Sherman K, Duda AM (1999) Large marine ecosystems: an emerging paradigm for fisheries sustainability. Fisheries $24: 15-26$

Silvani L, Gazo M, Aguilar A (1999) Spanish driftnet fishing and incidental catches in the western Mediterranean. Biol Conserv 90:79-85

Sommer F, Christiansen J, Ferrante P, Gary R, Grey B, Farwell C, Powell D (1989) Husbandry of the ocean sunfish, Mola mola. Am Assoc Zool Parks Aquar Reg Conf Proc: 410-417

Steele JH (1976) Patchiness. In: Cushing DH, Walsh JJ (eds) Ecology of the sea. Blackwell, London, p 98-115

Suyehiro Y (1942) A study on the digestive system and feeding habits of fish. Jpn J Zool 10:192-194

Threlfall W (1967) Some parasites recovered from ocean sunfish, Mola mola, in Newfoundland. Can Field Nat 18: 168-171

Walker MM, Kirschvink JL, Chang SB, Dizon AE (1984) A candidate magnetic sense organ in the yellowfin tuna, Thunnus albacares. Science 224:751-753

Wurtsbaugh WA, Neverman D (1988) Post-feeding thermotaxis and daily vertical migration in a larval fish. Nature 333:846-848

Wyllie JG, Lynn RJ (1971) Distribution of temperature and salinity at 10 meters, 1960-1969, and mean temperature, salinity and oxygen at 150 meters, 1950-1968, in the California Current. Calif Coop Ocean Fish Investig Atlas 15:1-188

Submitted: April 16, 2003; Accepted: October 16, 2003

Proofs received from author(s): January 19, 2004 